
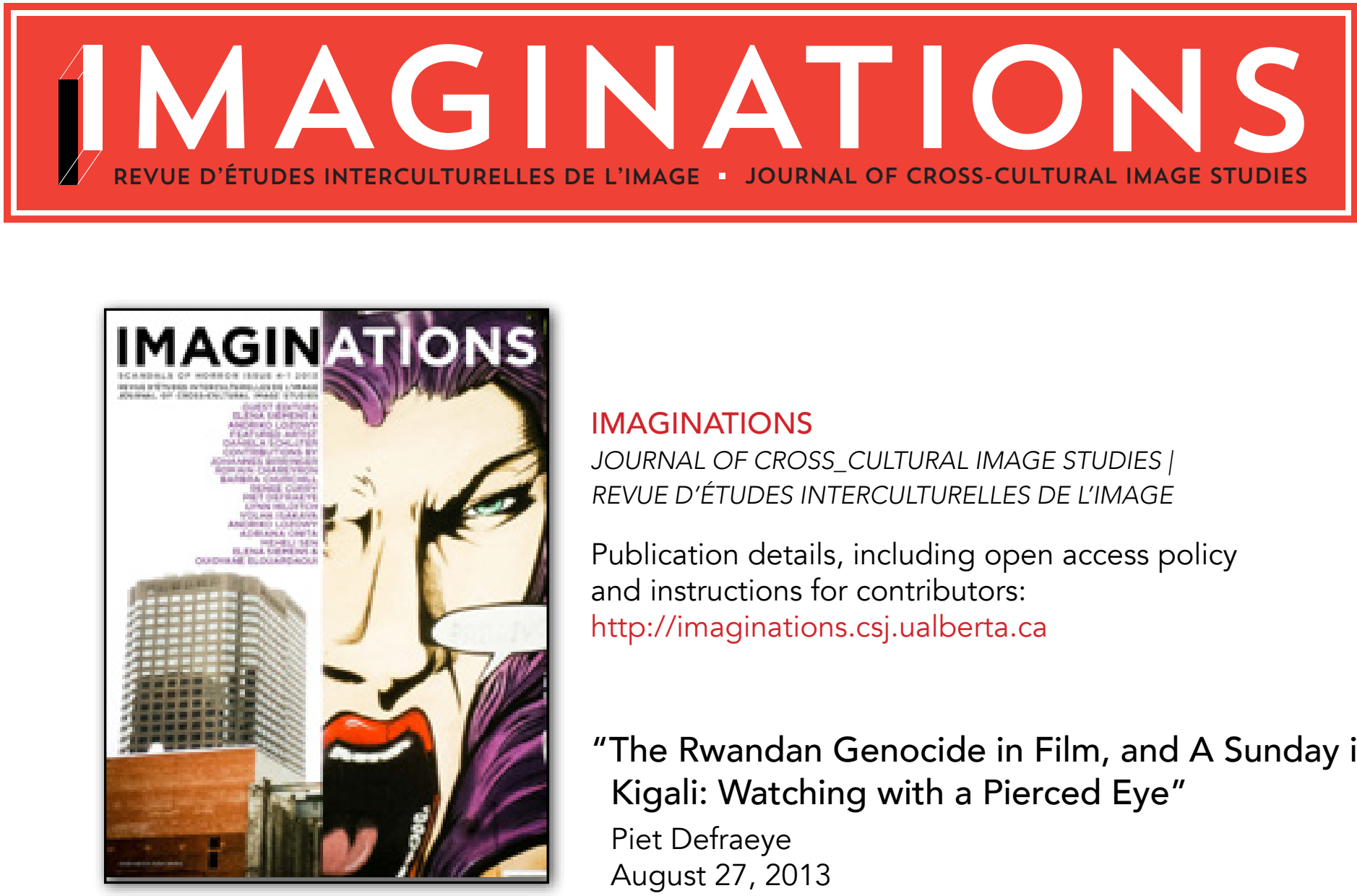

\title{
IMAGINATIONS
}

JOURNAL OF CROSS_CULTURAL IMAGE STUDIES |

REVUE D'ÉTUDES INTERCULTURELLES DE L'IMAGE

Publication details, including open access policy

and instructions for contributors:

http://imaginations.csj.ualberta.ca

"The Rwandan Genocide in Film, and A Sunday in Kigali: Watching with a Pierced Eye"

Piet Defraeye

August 27, 2013

To Cite this Article:

Defraeye, Piet. "The Rwandan Genocide in Film, and A Sunday in Kigali: Watching with a Pierced Eye" Imaginations 4:1 (2013): Web (date accessed) 82-105. DOI: 10.17742/ IMAGE.scandal.4-1.10

To Link to this article:

http://dx.doi.org/10.17742/IMAGE. scandal.4-1.10

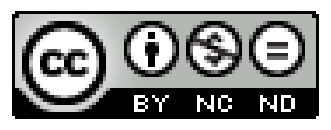

The copyright for each article belongs to the author and has been published in this journal under a Creative Commons Attribution NonCommercial NoDerivatives 3.0 license that allows others to share for non-commercial purposes the work with an acknowledgement of the work's authorship and initial publication in this journal. The content of this article represents the author's original work and any third-party content, either image or text, has been included under the Fair Dealing exception in the Canadian Copyright Act, or the author has provided the required publication permissions. 


\section{THE RWANDAN GENOCIDE IN FILM, AND A SUNDAY IN KIGALI: WATCHING WITH A PIERCED EYE}

\section{PIET DEFRAEYE}

Susan Sontag reminds us that film and photography have an extremely democratic heuristic poetics, and are quasi-universally accessible for signification, though at the same time, it almost always implies a prime target audience. The many films that have come out on the Rwandan genocide (1994) are no exception. Film has been a prime access source to this bloody event and dominates, particularly in the West, our remembrance and understanding of one of the most intense and grueling political conflicts in African history. All these films struggle with a compulsive need for structured narration, whether it is in their fable, or in the visual representation itself, while the historical events were certainly not experienced as part of a linear structure. At the same time, the films aim for historical credibility, or truthfulness, which is rendered through a variety of filmic approaches. The article discusses the fictionalization of genocide through film, and problematizes the quasiunavoidable documentary effect of filmic iteration. Robert Favreau's Un Dimanche à Kigali is analyzed in greater detail, as it offers specific strategies to the problem of filmic representation of genocidal violence.
Susan Sontag nous rappelle que le cinéma et la photographie ont un poétique démocratique etheuristique qui rend leur signification universellement accessible, tout en désignant presque toujours un public cible. Les nombreux films sur le génocide rwandais (1994) ne font pas exception. Le cinéma a été une source primordiale d'accès à cet événement sanglant, et il domine, surtout en Occident, le souvenir et la compréhension de ce conflit politique qui a marqué l'histoire de l'Afrique. Tous ces films démontrent un besoin compulsif de donner une structure au récit, qu'elle soit dans la narration ou dans la représentation visuelle, et cela bien que les événements historiques ne surgissent pas selon une structure linéaire. De plus, ces films vissent une crédibilité ou une sincérité historique accomplie moyennant une variété des techniques cinématographiques. Cet article évalue la mise en fiction du génocide a travers le cinéma et questionne le quasi-inévitable effetdocumentaire que produit son itération filmique. On y analyse «Un dimanche à Kigali » de Robert Favreau pour mettre en évidence ses stratégies d'investigation de la représentation cinématographique de la violence génocidaire. 
The Rwandan Genocide in Film, and A Sunday in Kigali: Watching with a Pierced EyeThe 1994Rwandan genocide is still fresh in our memory as a shocking tragedy, a gruesome conflict, during which between 500,000 and 1,000,000 people lost their lives. The memory of it is inextricably linked with the failure of the international community to preempt or intervene effectively. When the obviously pre-meditated hostilities broke out in all their viciousness on the night of April 6 1994, after the aeroplane that carried the Presidents of both Rwanda and Burundi, Juvénal Habyarimana and Cyprien Ntaryamira, was shot down over Kigali airport, there were few journalists and cameramen in the central African country available to document a 100-day killing spree rarely observed in human history. In the chaos of this murderous violence, the handful that were based in Rwanda either immediately fled to safety or were confined to a very small action radius. The conflict, in other words, was not well documented on television and in live reportage, which, contemporary witnesses suggest, is just one of the reasons why it actually assumed its horrendous proportions. However, since the victory of the Rwandese Patriotic Front, and the relative calm it brought to this small central African country in spite of the Pan-African and regional wars that have followed the Rwandese massacres, the iteration of the Rwandan genocide by a wide variety of artists and historians has exploded into its own genre, with novels and films leading this plethora of responses, from monuments and museums, over plays and documentaries to poetry and songs. ${ }^{1}$ There is, however, no doubt about the prevalence of film in the establishment of cultural memory about Rwanda's darkest months. This article examines some of the problems of cinematography as it relates to the Rwandan genocide, particularly its historical-documentary pretensions, its prevalent drive for visual and narrative structure, its struggle with the aesthetics of violence, and its impossible task of capturing death. In the second part of the article, I offer an analysis of one film in particular: Un dimanche à Kigali (2006), a Canadianproduced movie, written and directed by Quebec director Robert Favreau, based on the eponymous novel by Giles Courtemanche.

The films that emerged were either based on witness accounts and true stories of the events or, alternatively, on cultural narratives which were themselves often narrowly or loosely inspired by historical events. The latter is certainly the case for Courtemanche's novel, originally published in 2000, six years after the genocide, and subsequently widely translated across the globe, before it became the main blueprint for Favreau's film. Michael Caton's Shooting Dogs ${ }^{2}$ (2005) is based on the tragic and shameful story of a technical school that was the site of a major debacle in the United Nations: UNAMIR's failure to meaningfully intervene at the outbreak of the genocide. Hotel Rwanda (2004) is based on a key legend that emerged from the conflict, that of hotel manager Paul Rusesabagina, whose actual memoir, 
An Ordinary Man; an Autobiography, was published in 2007, well after the film's release and subsequent box office success. Many of these films have been shown in the commercial circuit and on television, with considerable attention, so it is no surprise that these movies have been major forces in the public dissemination of knowledge about the Rwandan genocide, and as such must be approached as major cultural discourse on the conflict. So major indeed, that quite often, some of them have assumed a venerable status of historical documentation, as in the case of Hotel $R$ wanda. On the other hand, one would also expect these movies to be part of a process of healing from the trauma that the political violence in Rwanda has left. It is problematic, in this context, that their primary audience is not a local audience, but a western-based audience. I will come back to this later.

While many of the film-makers under consideration have pro-actively pursued a level of authenticity unprecedented in the regular Hollywood film, all are quick to acknowledge the reductive and manipulative interventions of the film medium itself. Michael Caton, for instance, had to reduce the number of priests that were working at the Don Bosco École technique officielle from five to one, and, as Dauge-Roth points out, "no white priests stayed at the ETO to die with the Rwandans after the Belgian forces left" (176), unlike the strategically named priest Christopher, brilliantly realized by John Hurt, who, in the end, shares the fate of the hundreds of Rwandese he is trying to protect. What may seem like minor details in the fable are ultimately crucial in the generation and management of affect in the viewer's reception and response. Similarly, Terry Georges' film Hotel Rwanda, which has by far been the most successful in terms of box office and cultural impact, illustrates well the privileged position the medium of film has in the genre of genocide memorialization, but more importantly also in the shaping of a specific and/ or collective memory of the Rwandan genocide. Hotel Rwanda, like most films on the Rwandan genocide, assertively foregrounds the fact that its narrative is based on real events, thus giving it an aura of authenticity, reliability and truth. Yet, considerable critical work has since been done on Hotel Rwanda and other films, that challenges the films' veracity and underlines choices and manipulations which make these films more palpable, and therefore successful in a Hollywood sense: they by and large generate comfortable audience positions that find their balance in easy and simplified -if not downright erroneous- understanding. As we shall see, a film like $A$ Sunday in Kigali is surely culpable of this sort of manipulation in the set-up of its fable, however, it also adopts a strategy that at the same time questions the power of its own - and therefore also the viewer's - point of view. At this point, it is useful to talk about the target audience of these films.

Susan Sontag, in response to Virginia Woolf's observations about war iconography, wonders whether there is 
a collective and identifiable "we" that responds to imagery of atrocity: "No 'we' should be taken for granted when the subject is looking at other people's pain" 7). Most of the Rwanda-genocide films, however, are clearly aimed towards a western audience and have a collective we in mind. Michael Caton-Jones says on his Shooting Dogs: "I wasn't making the film for Rwandan audience. ... I I made it for people who've never been there and have no stake or even an interest in it" ("Interview6). The film then, through its shocking narrative, is meant to jolt the western spectator into securing an interest, whether through indignation, consternation, or guilt. Raoul Peck's Sometimes in April (2004) has Rwandese characters as the key-players in its fable, yet here too, the audience in mind is a western audience. This focus is also made clear in Peck's determination to anchor his story within a narrative of colonization and its aberration, as he begins the prologue to the film with a sequence of overlapping maps that progressively show the colonization and exploitation of central Africa. The first spoken words in Peck's film are: "Where did it all begin?" The answer, the film makes clear, is to be found in the botched Belgian colonization (we see historical footage of one of the first visits of a milk-faced Belgian King Baudouin) and the subsequent paternalization of the same region in post-colonial times (the next historical clip is Bill Clinton's 2004 visit, adroitly apologizing to a class of Rwandese schoolchildren for the USA's non-intervention). Peck's rhetoric is clearly aimed at a western collective we.
The collective $w e$ of spectatorship is also defined in the dominance of Caucasian characters on the screen. Just about all films that have come out have an over-representation of white characters in their fable of this central-African event, and are focused somehow on moral dilemmas pertaining to their white characters, which, in the actual historical events played a peripheral role. Dauge-Roth calls this privileging of white identity "justifiable in that it allows for points of identification and elicits feelings of sympathy from viewers, and maybe even a sense of historical culpability" 189). One film that stands out is Nick Hughes's 100 Days, which was the first feature to come out on the Rwandan genocide in 2001, and is often referred to as the least historically revisionist. While its two lead characters are both local Tutsi - in itself a rare feat in the filmography on Rwanda-- it probably has the largest quantity of white characters casted. However, in contrast to other films, just about all of these are quite overtly racist or prejudiced, and also quite cowardly in their behavior. Hughes' film was not a great box office success, and while low budgets and amateur acting may have something to do with this, the strategy not to provide his spectatorship with an easy way-out in terms of salvation or redemption of the responsibility of the West may well be the main factor. It is all the more surprising, since his film is one of the only ones that actually provides a sense of authenticity in terms of it being less staged or acted. Produced by Rwandan film maker Eric Kabera, who lost many of his own 
family members in the genocide, the film was shot in Rwanda in the Kibuye area, using mostly locally available non-professionals, often survivors as well as perpetrators. The film is a good example of the trappings and dangers with which filmmakers are challengeh. It is clearly based on solid research - in this case the first-hand experiences of just about all that were involved in the film, including director, producers, and actors, and the film's historical reliability is very high - almost at a documentary level. Furthermore, it is unapologetic in its focus on the responsibility of the West in the lack of any serious attempt to prevent and/or effectively intervene. The film, however, struggles with its own aesthetics, as the violence shown becomes quite watchable, mostly because of cinematographic choices and the seductive allure of Hughes' expert camerawork, this in stark contrast to a very simple dialogue -in Kinyarwanda and in English, also a rare feat-delivered by charming, but often awkward actors. While the movie, like all the others, is really only available to and geared towards a Western audience, the most important impact of the film is probably on a local level, where it contributed considerably to the local economy and the (re-)establishment of local film expertise while being researched and shot. Because of its community-based genesis, it also became a catalyst for memorial discourse to find its way into the local public arena.

In more general terms, and irrespective of the implied audience, there is something very peculiar going on as to the affective and cognitive impact of these films on the establishment of a collective memory of what happened in Rwanda in 1994. Dauge-Roth aptly calls these feature films on Rwanda "vectors of memory that reach a large audience" 192), and their role in shaping and impacting on a dominant view of the Rwandan genocide afterthe-fact can hardly be underestimated. At a very basic level, we cannot forget that film, as well as photography, is an extremely democratic heuristic medium. Film and photography have a very wide base of understandability. While film analysis courses and extended exposure can certainly help in the understanding and appreciation of the depths and layers of any film, the novice and uninitiated film spectator/consumer is a perfectly legitimate authority in his or her spontaneous response to and engagement with a film. Sontag points out that critical investigative reports and bulletins, or creative responses like novels and plays have a specific readership, whose access depends on the work's "complexity of thought, reference, and vocabulary." In contrast, however, "a photograph has only one language and is destined potentially for all” 20). While we can unquestionably take issue with Sontag's suggestion here that photography (or film) has a simple semiotic system, we agree that its heuristic potentiality is indeed quasiuniversal. The image speaks for all. We cannot say the same thing of Primo Levi's novels. Furthermore, one thing that unites all films made on the genocide so far is their realist aesthetics and their fairly traditional narrative structure, 
through which the story unwinds itself with a purposeful, teleological diegesis, with clear causes and effects - often didactically explained or guided through prologues- and with unmistakable protagonists and antagonists, all moving towards a denouement - often tragic, but nevertheless presenting a fantasy of closure. While the events portrayed may be mindboggling and chaotic, there is an internal coherence at work which makes us want to see the end of the movie's plot, which we mistakenly collapse with the historical events themselves, thus allowing us to think of the fictional closure - The End - of the movie as the end and closure of the historical conflict itself. For the spectator, it is a double victory. Not only is the un-representable dystopian madnessdmolded into a comprehensible format, it is also, now, understood, appropriated, concluded, and therefore overcome. The filmmakers surveyed for this analysis use a variety of strategies, which come back time and again. The narrative structure that is geared towards closure, and is coherently framed, is usually anchored within a basic set of historical references. As indicated, these historical anchors are often explicitly provided in prologues and epilogues, or through voice-over or text slides. In some films, the historicity is provided explicitly through historical footage. Hotel Rwanda, for instance, starts with a voice-over extract from a hyper-hateful but authentic radio diatribe on Radio Télévision Libre des Mille Collines (RTML). Raoul Peck uses historical footage of King Baudouin and President Clinton's visits to Rwanda in
Sometimes in April, which he follows up with an extensive and fairly detailed - almost didactic - historical account of the conflict through a sequence of text slides. When the film proper begins, it is invariably the story of some hero or victim as anti-hero. These (anti-) heroes are presented as emblematic for what happened, they represent the wider real story that is being told, and in doing so, they acquire a super status of what Sontag calls "star witnesses, renowned for their bravery and zeal" .33). While these films want their story to be the genocide, our focus is invariably on the tragic and/or heroic fate of a particular individual or set of individuals.

A key question in all of this is obviously whether film can legitimately add anything to our understanding of what happened in Rwanda during those 100 days in 1994. Or, more succinctly: can genocide be filmed at all? As to journalistic coverage of the genocide, it was in many ways similar to the filmic evidence that exists of the Holocaust, which is the sparing but horrendous filmic documentation on the occasion of the liberation of various concentration camps in 1945: that is, after the facs! As the genocide broke out, journalistic coverage became extremely precarious in Rwanda. Local journalists were either partisan members of the extremist press -mostly Hutu-leaning, like Radio television libre des mille collines (RTM), or the monthly extremist newspaper Kangura, or were themselves targets of the violence during the height of the carnage. ${ }^{4}$ The international organization Reporters sans frontières 
estimated a total of at least 49 local journalists to be murdered in the four months following the outbreak of the murderous inferno Chrétien 389). Very few foreign correspondents remained inside the country in the first weeks after April 6, 1994, and only a handful managed to find access to the country and adequately report on what was happening during the first few weeks. Even fewer managed to stay for sufficient time to actually be able to give a fair testimony of the actual scope of things during the 100 days of carnage. Three famous examples of the latter sort are George Alagiah, Nick Hughes, and Els De Temmerman. With a dozen or so colleagues based in Nairobi, BBC-correspondent Alagiah managed to enter Rwanda in May, a full month into the atrocities, and was one of the main instruments through which the world could visually witness the most shocking aspects of the events in a mode which has become known as "let the picture tell the story." A month earlier, independent British cameraman Nick Hughes entered Rwanda for a brief period in the first week of the genocide and famously filmed an actual killing in the streets of Kigali. I will come back to this filming later in my discussion. A month earlier, precisely four days after the downing of the presidential plane, Els De Temmerman, arrives in northern Rwanda through Uganda, and facilitated by the Rwandese Patriotic Front, covers the initial events for the Dutch newspaper de Volkskrant and the Flemish-Belgian radio station BRTN as one of the very first and only journalists in the field. Only ten days later she is forced to flee to neighbouring Nairobi, Kenya, and writes in her concluding summary of fragmentary impressions, as she waits for her plane to take off from the devastations of Kigali airport: "All journalists have now left, together with the last few whites. As if the narrative stops" 32 , my translation).

Meanwhile we know that the narrative surely did not stop there, nor the historical events - however fragmented that account will forever remainnor the compounded filmic narrative that has since developed. And the specific narrative within the films under discussion certainly is never disrupted or halted. Watching these various cinematographic documents, the question whether genocide can überhaupt be filmed remains central. Sontag's assertion that to "catch a death actually happening and embalm it for all time is something only cameras can do" .59) is strange and obviously extremely reductive. To give her credit, though, she later also admits that photography only really adds to the lack of understanding of death. Photographed, the dead victims of violence "are supremely uninterested in the living: in those who took their lives; in witnesses- and in us" 125). Neither film, nor certainly photography have the capacity to actually catch anything truly meaningful of this mysterious transition, and especially of the agonies in which it is often embedded. A photograph of a corpse is often as distanced and remote as a plaster death mask, and only removes the spectator from the hauntingly liminoid character 
of death itself. The Belgian painter James Ensor has a series of paintings and drawings of his dead mother; they were kept together with a pair of photographs of her laid-up corpse, the whole collection made over the span of four or five days while his mother was laid up in their Ostend home in 1914. The photographs themselves are cold documents, without any emotion, just, as it were, providing objective proof of a cold death. His drawings and paintings, on the other hand, while still showing a cold object that has no response to the viewer and has no subject position - a cold still-life, if there ever was one! - collectively document a huge turmoil in the artist's own subject position. One of these shows his dead mother with wide open eyes in a praying pose ${ }^{5}$, the others are minimalist pencil drawings, one of them in colour pencil, that document the emotional turmoil of an intensive mother/son relationship. The 1915 painting, My Dead Mother (Todts 220) that was shortly thereafter completed, creates a wider scene, witd a tray with pharmaceutical bottles in the foreground, hinting at a process of disintegration and struggle for the aging woman, who was a dominant force in the artist's life. The image's embalming impact to which Sontag refers to in her observations about photography takes place, clearly, outside the paintings: these pictures witness and document Ensor's love for his mother and his strong mother attachment, and his subsequent sense of loss. Sitting there for hours, day after day beside the corpse of his mother, drawing her in these simple and honest works before the more formay ritualized goodbye of tha burial has produced a hugely moving documentation of his love, grief, sense of loss, as well as his sheer fascination with the corpse itself. The photographs that feature the same dead woman, on the other hand, add virtually nothing to our perception and understanding of this struggle. More to the point: the entire series of photographic documents says nothing about his mother's own struggle with death, however far removed her peaceful death in a seaside resort was from a violent massacre in the marshes of Rwanda.

Karyn Ball, in her immersive discussion of the Holocaust as an object of both inquiry as well as desire, reminds us of "the trope of unspeakability," which refers to the acknowledgment of a radical "moral otherness of the atrocities" 36), so that they cannot, in fact, be iterated. This contrasts with an abundant discursive practice, be it in film, prose, or critical discourse (this very essay in casu), which obviously transgresses the taboo of unspeakability. I would add to thi, the obvious demand for this kind of iteration in cultural consumption. She speculates that these bountiful transgressions have less to do with the moral excess of the referenced violence and more with a compulsive but "shameful fascination" with the transgression itself, which "violates deep held bourgeois codes" 37). The spectacle, re-created and re-presented in these films functions as a trap of visibility, to use Foucault's words, in which our eye is watching with a double lens: its gaze marks out its intake as "objects/ 
specimens of information and of institutional, clinical, and/or voyeuristic interest" but at the same time there is a self-consciousness of a transgressive act, which, in a way, becomes a friable and therefore vulnerable or unprotected performance of watching. Ball describes it as being "caught in the act of stooping to peer through the keyhole" .27). Or, to use the kind of imagery typical for Rwanda-films, we watch the machetes cleavg through bleeding flesh coldly and clinically, as part of an economy of knowledge (what happened?, the story, the characters, etc.) and of assimilation (we recognize and condemn the violence). Yet, at the same time, our watching itself becomes asfractious act, and has moments of hesitation, as we catch ourselves watching what must not be watched. Our watching eye is figuratively pierced: as we are safely absorbed, watching the machete-props wielded in front of the cameras and actors, our gaze also draws closer into the watching itself, and is inevitably wounded by the sharp steel points and blades that dangerously hack right in front of our spyhole, into vulnerable and mortal flesh.

Madagascar-born French journalist Jean Hatzfeld stands out among the historiographers of the Rwandan genocide for his meticulous recording of post-factum memories, traumas, testimonials, and sensibilities among surviving victims and perpetrators alike, armed not with a camera, but with pen and notepad, and a voice-recorder. In 2003, four years after having covered the final weeks of the genocide, he returns to the village of Nyamwiza, in the south-eastern Bugesera region, in search of survivors. By sheer coincidence, he also witnesses filmmaker Raoul Peck's elaborate team in the village while cast and crew face huge logistical and artistic problems trying to re-construct and put to film the refugees' horrid "reptile life in the marshes" (Hatzfeld.99) for the film Sometimes in April. This rather surrealist experience leads him to ask survivor Innocent Rwililiza about the striking absence of photographic material of the actual killings. Rwililiza's answer is startlingly self-evident and to-the-point: "There aren't any photos because there is no place for photographers on killing fields, such as our marshes and forests. No pathway of any kind along which a foreigner might slip among the killers, the killed, and those who have yet to be killed" (Hatzfel. 98-99). And Rwililiza continues with captivating clarity:

A genocide must be photographed before the killings - to show clearly the preparation, the faces of the leaders, the stockpiled machetes, the complicity of the French soldiers or Belgian priests, ... And the genocide can be photographed afterward to show the corpses, the survivor's haggard faces, the arrogance or shame of the killers, the churches piled with bones, the events in Congo and Canada, the penitentiaries, the ceremonious foreigners visiting the memorials. (Hatzfel.100)

The survivor's comments push the issue of representation well beyond the logistics of what is possible, and present it in its full ethical dimension. 
Filming death, as we know from sequences such as Saddam Hussein's execution, quickly disintegrates into voyeuristic obscenity. As already mentioned, one of the very few instances where the Rwandan killings are actually documented on film is Nick Hughes' footage of the slaughter of a father and his 20-year old daughter, later identified as Gabriel Kabaga, an auto mechanic, and Justine Mukangango.Hughesfilmed the gruesome event on April 11, 1994, from the rooftop of a French school in Kigali's Gikondo district, flanked by a distressed UN paratrooper who, helplessly, guided the cameraman to the scene through the scope of his rocketlauncher. The entire scene took no more than 20 minutes to film, yet Hughes had to turn off his camera periodically, "because he knows that he is almost out of tape and fears his batteries are running low" Thomson). 6 The grainy and jumpy footage was broadcast that same evening on $\mathrm{CNN}$, German ZDF, and Australian Broadcasting, and other channels, but without much further impact or effect. In fact, the total of three minutes and 12 seconds of video caused bigger waves years later, when Toronto Star journalist Allan Thompson managed to reconstruct the circumstances and identify both victims as well as some of the culprits. Hughes himself dealt with the ethical questions and feelings of guilt of his role as filmhistoriographer in the bloody conflict, in a 2008 documentary Iseta, Behind the Roadblock, which focuses on the circumstances of this killing and on the aftermath, including the quest for justice. The original document is obviously hugely important. Not only does it offer what is most likely the only actual killing during the Rwandan genocide documented in film, out of the hundreds of thousands of cases, ${ }^{7}$ it has also inspired many other representations in films about Rwanda, and is often quoted as an illustration of both the media's disseminating power and, at the same time, its inadequacy to actually intervene and stop the violence. It was also used as forensic evidence to incriminate, try, convict, and incarcerate one of the killers, Alexandre Usabyeyezu, who adamantly maintains he has been wrongly identified in the blurry, fragmented film, further illustrating its own inadequacy and fragility as revealing or reliable documentation. The overwhelming affect of Hughes 3-minute film, however, is the sense of jagged and quasimisplaced intrusiveness - so shocking that it brings about a paralyzing feeling of futility and ineffectiveness. Innocent Rwililiza's response to Hatzfeld's query about photographic evidence is helpful to understand the impotently explosive power of Hughes' witness document: "the intimate truth of the genocide belongs to those who lived it" (Hatzfeld 100).

wIntimacy is surely not a word that can easily be applied to the numerous Rwanda films that have come out since. The camera's voyeuristic eye is by definition an intruder into any potential intimacy, especially when it concerns death. In various films on the genocide, death is mostly present through big sweeping camera shots of piles of corpses 
along dirty roads and at road checkpoints. To add to the effect, Raoul Peck uses some historical footage, includins it in his film Sometimes in April. It comes without warning, and presents obvious ethical questions for the viewer, who has settled for the convention of reenactment and is suddenly confronted with the uncertainty of real-life imagery of carnage. Perhaps this is another occasion of watching with a pierced eye, where our perception is violently torn between the fable and the real. It is similar to Krzysztof Kieslovski's film Rouge (1994), which mixes fiction with historical footage of the sinking of the Zeebrugge-Dover ferry Herald of Free Enterprise, which capsized just outside of the Zeebrugge harbour, with almost 200 victims drowning in The Channel. The inclusion of the documentary coverage of the sinking ship in the middle of the chaos and logistical turmoil of emergency operations, in which Kieslovski smartly inserts his characters, is extremely jarring and remains completely un-acknowledged within the film. For anybody who participated in the rescue operations and the nightmarish outcome in the days following, Rouge remains a film that is hardly watchable. In Peck's case, unlike Kieslovski, the inclusion of historical footage of carnage, at least, is within a story that itself is the narrative or representation of a historical genocide. The documentary images are then used as a reinforcement of the film's non-fictionality (though the details of the story itself of Sometimes in April are fictional). Peck anchors his film in various places referencing historical events by means of direct quotation, varying from the above horrid footage, to a soccer match that was being broadcast of the eve of the $6^{\text {th }}$ of April. Clearly, all the cinematographers of the Rwandan genocide have struggled with the (re-)creation of a narrative that is not only based in historically true facts, but must also be believable as history as it develops in front of its viewers. Their films are steepedhin a rhetoric of historical conviction, promulgated by means of direct historical documentary quotation or historical explanation in their prologues and epilogues. Many of these preamble summaries or concluding commentaries comprise gross generalizations that present the conflict as a tribal clash between two homogeneous groups. I agree with Dauge-Roth's conclusion of his analysis of a number of films, that these preand post- filmic annotations have an immediate impact on the spectator's heuristic framework. They create "the promise ... of a communally shared rationality and morality, which is at least encouraging to viewers as they are about to realize that by definition, genocide destabilizes the very idea of shared humanity in its negation of a part of humanity" 208).

In the second part of this discussion, we will now have a closer look at one film in particular, which responds in a very specific way to some of the challenges outlined above. Robert Favreau's Un dimanche à Kigali is a film that, like most others, presents a coherent story, as seen through the eyes of a white person residing in Rwanda. The movie 
is an adaptation of Quebec author Gil Courtemanche's novel Un dimanche à la piscine à Kigali, which was first published in 2000 and was quickly translated into English and a handful of other languages. The novel has been widely critiqued -often negativelyabout its graphic descriptions of violence and especially its remarkable sexualization of this violence. my own analysis of the novel concludes with a nod ts its ambivalent success of restoration and representation of the events it is steeped in, and warns of the ongoing disposition in critical analysis to search for an essential truth in cultural discourse on the genocide Defraeye). Heike Härting, however, refers to the book's "pornographic gaze" and "pornographic rhetoric" (2008, p. 69-70) to denote the novelist's radical choices for a sexualized language of violence. In comparison to the book, Favreau's 2006 filmic adaptation is fairly tame, and while there is certainly sex, blood, and violence, their graphic display throughout the movie -in contrast to Courtemanche's novel-is contained and quite limited, perhaps more contained even than in any of the other genocide movies that have been produced. It may well have been a cautious attempt by the director/ adaptor not to be subjected to the same accusations of being obsessed with imagery of sex and violence. Like the novel, the film thematizes the notion of filmic documentation as a meta-filmic motif that comes back throughout the movie. Courtemanche prefaces his novel with the notice: "Ce roman est un roman. Mais c'est aussi une chronique et un reportage" (Un dimanche. 9), thus underlining the testimonial function of his writing. In Patricia Claxton's English translation of the novel, "reportage" is turned into "eye-witness report" (A Sunday viI), which foregrounds even more the authentic and reliable nature of his writing, as well as its revealing potency. The novelist wants to present a historical indictment against the perpetrators of the violence - there is no doubt in the novel that these are the radicalized Hutus - and against the shameful failure of the outside world to meaningfully attempt to preempt or intervene.

While Favreau's Un dimanche à Kigali does have a documentary function, it does not have the same indignant tone as the novel, mostly because the film's narrative is focused on the reconstruction of the love-story between the two main characters. The film is book-ended with the frantic search of protagonist Bernard Valcourt, returning to Kigali at the end of the ethnic violence, trying to find out what happened to his Rwandese fiancée, whom he was violently separated from during their frantic getaway at the outbreak of the ethnic violence three months earlier. Valcourt is a middle aged Canadian journalist played by Quebecois actor Luc Picard), who has spent three months in Rwanda to make a video documentary on the AIDS crisis, only to find himself caught up in the political and personal quagmire of genocidal aggression. While he hangs around at Kigali's posh Hotel des Mille Collines, he falls in love with a 
young and slender Rwandese waitress, named Gentille Sibomana played by Senegalese Fatou N'Diaye), who has a stereotypically Tutsi appearance, but carries a Hutu stamp in her passport, which of course, is taken away from her at one of the many checkpoints we go through in the film, so as to make her ultra-vulnerable for the upcoming onslaught. Valcourt and Sibomana, incidentally, are two of the very few characters in the film with a family name. Valcourt's surname is spread all over the film, often preceded by the epithet "Monsieur," and thus becomes a very public identity. We get to know him more as Valcourt, than by his first name, Bernard. Gentille's.surname, on the other hand, is said only twice and fleetingly in two intimate and private moments between the two lovers: once during a mock wedding ceremony, and a second time during his offering of a wedding ring to her. Just about all the others characters, Maurice, Rock, Emerita, Victor, Raphael, Manu, Célestin, Agathe, Cyprien, Modeste, Désirée, Élise ... black or white, victims or perpetrators, only have a first name. For the viewer, it makes it a challenging narrative to follow just in terms of understanding who is who. But most of all, its impact is on the emblematic function of the film. What it does is, on the one hand, level out the story of the genocide so that the fable affects everybodd, irrespective of who they are, or the name they have, or their race or ethnicity, and, on the other hand, it actually individualizes the story to very specific individuals -with a first name and a face, a smile, and a particular

IMAGINATIONS • ISSUE 4 - 1, 2013•94 impression theymakeonus, thespectator. One individual in the film is not named at all, though his name is paradoxically the best known of all: general Roméo Dallaire, military head of UNAMIR, the United Nations' inadequate and feeble military presence in Rwanda at the time of the outbreak of violence. The first long shot we have of him, in a long confrontation with Valcourt, is of his back, while he's looking out of his office window at a tense Kigali: the back of a white man in uniform, no name, and a self-declared friend of the Rwandese. Valcourt came to plead for a more pro-active engagement and for the protection of his best friend Manu, the latter apparently modeled after the Rwandese politician-businessman Landouald. The confrontation between Dallaire and-Valcourt is a bleak scene, which highlights Dallaire's impotence to do anything really preventative, yet it also foregrounds the soldier's indignation and internal rage, which again is modeled after Roméo Dallaire's post-genocidal public activism. The lack of a name of this white man in uniform, apart from the name being redundant, as especially the Quebecois and Canadian target audience of the film would have instantly recognized their general (played by well-established Quebecois actor Guy Thauvette), underscores the metonymic function of Dallaire as a westerner who witnesses and knows, and has the theoretical power to intervene, but lacks the political and financial commitment and means to do just that. Instead, he just stands by, his back to the camera, looking on the capital of a country he professes to have a deep love for. 
It is no coincidence that in this very same sequence, Valcourt emphatically declares the family name of two other people: that of Cyprien and Georgina Munyankore. ; he found them brutally slaughtered, together with their child, in the preceding scene by the Interahamwe (Hutu) militia. Apart from Gentille, these are the only Rwandese fictional characters in the film that are identified y their full names, ${ }^{8}$ and their perlocutionary being named is a stark contrast to the thousands and thousands of anonymous corpses left by the violent torrent of genocide. The consistent use of first names is even implausibly maintained in Père Louis' breaking of his confessional vows, when he declares in front of Valcourt's video-camera how Théoneste, one of the Rwandese Colonel's has confessed the total extermination plans of all Tutsi's and moderate Hutus, not sparing anyone, not even women and children, and giving priority to kill anyone in leadership, including "Emanuel, Faustin, the prime minister Agathe... ." Again only first names are used, though Valcourt seeks quick confirmation in this particular case that père Louis indeed refers to the historical Théoneste Baggasora, a retired army officer who was in charge of the Interahamwe at the time of the outbreak of violence. Père Louis's courageous testimony - "it is too late to be too scrupulous, " he justifies breaking the sacrament of confession he is bound to - provides Valcourt with a powerful document. When Père Louis asks him to take a pen and note-pad, Valcourt says: "I have something far better than that!" and takes out his video camera. The videotaped testimonial that follows becomes a central scene in the film for several reasons, as it demonstrates that the imminent atrocities had been well organized and prepared, but also that knowledge about the genocide was available beforehand for outside observers. However, more interestingly, it also highlights the power of filmic reporting itself in these circumstances. For Valcourt this is a crucial document in his engagement to help prevent the, in his mind, unilateral violence. That same evening, he is on the phone with Montreal to have Père Louis's insider informationtakenup bytheinternational press, though, not surprisingly, it is hardly acknowledged or appreciated by that same press (and its consumers), and the testimonial itself fails in its incriminating power because of the improbable use of only first names. This demonstration of Valcourt's impotent efforts reminds us of an earlier taped interview with his friend Cyprien, just before the latter's violent assassination. Cyprien admonishes him to leave the country immediately, so as to save Gentille. When Valcourt counters that he owes his many friends the successful completion of the documentary he is working on, Cyprien reminds him that "Cameras are no match to machetes," while we hear the strident slogans and demonstrations of the Interahamwe approaching in the background. The overwhelming impression the, is indeed that Valcourt, armed with his videocamera, blindly and naively failed to save his treasured Gentille from the murderous violence that is surging 
all around them. Filmmaker Robert Favreau truncates his movie with regular videotaped sequences taken by Robert Valcourt himself as part of the latter's professional preoccupation of making a documentary on AIDS in Rwanda. These insertions allow the movie to have a very flexible time reference, comprising the time before the actual start of the movie, when Valcourt returns to the killing field in order to try to find his Gentille or what became of her. We are alerted of this kind of documentation within the film by the red-coloured "Rec" or green "Play" in a corner of the image. Favreau's technique certainly underscores the montage character of the film, and thus reminds us of its post-factum artificiality, and may well help to create the conditions for some kind of aesthetic distancing so as not to get lost too much in the anticipatory dynamic of suspense the film inevitably creates, as underscored for instance by the fairly traditional use of music for specific kinds of scenes throughout the movie. Valcourt's camera work is a form of archiving, and thus gains political significance within the project of documenting a genocide, which, as we know, remained largely invisible to the outside world. Yet, what we see in these historical insertions in the movie, apart from the more intimate mementos of Gentille, are mostly interviews with witnesses and role-players of the Rwandan scene. While Valcourt's videography certainly reminds us of the restorative nature of the genocide film in general, at the same time, it also underscores its paralysis to do just that.
His failure to document any of the actual violence is a good reminder of genocide survivor Innocent Rwililiza's point that genocidal violence cannot be photographed. This is indeed the case in more ways than one in this film. There is, of course first, and foremost the practical improbability of the murderous act being available to be filmed, apart from the notorious and covert 3-minutes of documentary film shot by Nick Hughes (cf. supra). A movie, one might say, with all its tricks and technical possibilities, may then be an ideal means for a reconstructive answer to this lacuna. Yet, there is also the purely intimate aspect of death and dying that Rwililiza refers to, particularly when it concerns a violent death. Filming a butchering of another human being contains an unavoidable facet of obscenity, and incriminates not only the perpetrator as executioner, but also implicates the gazing filmmaker in this obscene incrimination as facilitator. It is no different within the framework of a fictional tale. Bernard Valcourt, with his privileged status of international co-operant, desperately wants to avoid being a facilitator of the violence he sees emerging around him, and hopes the one weapon he has, his camera, can weigh in on the events. Not so, of course: while Valcourt desperately stays in Rwanda in order to try to document, and hopefully help to prevent the worst-possible scenario, he remains powerless and utterly without any impact with his camera. His actions, in other words, are a concrete showing of the notion of white guilt that surrounds the aftermath of the genocide, of not 
having intervened, while perhaps the intention was there, and certainly the good will, but not the wherewithal, and even less the putting oneself on the line. The spectator knows (and puts his or her hope in that knowledge) that Valcourt's Canadian passport (and pack of dollars) remains a steadfast way-out ticket, as it eventually and unavoidably is, in stark contrast to the fate of his beloved Gentille.

Though A Sunday in Kigali surely makes us stand still and reflect on the events presented in the film, it foregrounds the camera's powerlessness to intervene or prevent. Moreover, in its focus on witness-documentarist Bernard Valcourt, the film is grounded in the failure of the camera to capture anything truly essential about the Rwandan genocide. As Susan Sontag reminds us: "Harrowing photographs do not inevitably lose their power to shock. But they are not much help if the task is to understand" .89). Favreau's reflexive strategy of constant insertion of Valcourt's videotaped fragments draws our focus away from the account of actual violence that we think of as the theme of the film, and makes us refocus on the re-presentation itself of this genocide, as opposed to being lost in the charms of mimetic realism of a pseudo-present within a chronological narrative. This reflexive approach also undermines the spectator's position as a consumer of violence, a perspective for which we have been well trained by television and movies alike.
If the actual theme of $A$ Sunday in Kigali is its own failure to say anything really meaningful and authentic about the genocidal violence, how then does the movie deal with the carnage of the genocide? As already indicated, the actual violence shown in the film is fairly contained, and surely in comparison to the book on which the movie is based, it seems like Favreau, who also wrote the screenplay for his film, put Courtemanche's novel through a major cleansing filter. The group-rape and butchering of Georgina and Cyprien are among the most graphic in the entire movie, and even these scenes are more suggestive than anything else. The bloodied back of Georgina on a mattress on the floor, and a close-up of a couple of machete blows that land on the back of Cyprien are sufficient to indicate what'is happening in a starkly concise and short sequence. Favreau shows us the brutal casualness of the violence of its perpetrators. His main interest, however, is the traumatic impact of this bloodshed. When Valcourt and Gentille visit Cyprien's house the next morning, they are confronted with the mutilated corpses of both parents as well as their children. Valcourt finds a torn photograph of the family, which he later crudely tapes together as the only visual proof of the very existence of these people, while the sutures of the restoration will be a permanent reminder of the murderous rupture. Gentille stumbles on symbolicallynamed Désirée, one of Georgina's children, who survived the massacre by hiding under a bed. She will adopt the girl as her own. 
The film also suggests violence and aggression at road-checks, with agitated men wielding machetes, and glimpses of piles ofbloodycorpsesin the background, though they are hardly ever a major focal point in the cinematography. This is in great contrast with other Rwandan genocide films. Michael Caton-Jones' Shooting Dogs, for instance, a film which also foregrounds the problem of documenting violence, contains a scene in which the young main character Joe witnesses a middle aged man being slaughtered with a couple of machete blows, while he himself and the BBC team he is travelling with is also gravely threatened by a road patrol. Caton-Jones' masterful camera-work and composition in this scene registers Joe's initiatory fascination with the murderous act, thus representing the film's spectator with whom he shares a compulsive need to watch. The ambushed BBC team, furthermore, are paralyzed in their documentary mission to show and have people look by the militia-men, who prevent them from filming what cannot be filmed but should be filmed. More importantly, their immediate survival from this harrowing situation seems, precisely, to hinge on their NOT looking at the murderous scene that materializes around them, and from which they can hardly divert their gaze. Another occasion for which the image of the pierced eye illustrates the visual poetics and its affect, as if we are condemned to watch with a gazing eye from which the retina is folded out.

However skillfully done by actors and cameramen, the consumption of these violent episodes in films on genocide remains problematic. While the authentic is not available, or if available must be dealt with extreme respect and caution, the re-enactment inevitably produces an obscene dynamic between what is shown and the historical gruesome event that it is modeled on, as well as between the image and its consumers. Indeed, the obscenity of such imagery makes them literally ob-scene, or off the stage, which means that they belong to a cultural discourse that is traditionally obscured or excluded, except within the context of precisely that re-enactment where their inauthentic character makes them ready for legitimate consumption. It is a sort of consumption for which we have been well trained, as this kind of imagery is more or less the basic diet in our contemporary cultural ingestion. British playwright Edward Bond, whose plays often thematize what he calls our extremely violently structured western society, uses cruelty on the stage quite often in his plays - "I write about violence as naturally as Jane Austen wrote about manners".3) - and gives it a therapeutic function, thus aiming at shaking the audience emotionally. Bond's so-called Aggro-effects are akin to terrorist tactics, their use equally justified "by the desperation of the situation" 113). While the situation was positively more desperate in Rwanda in 1994 than in Bond's industrial hinterland of the British midlands in the early seventies, using this hyper-realism on the stage has certainly a very different impact on the spectators in the theatre than on a film audience. A Sunday in Kigali tells the story of a quest for this violence, as 
it becomes Valcourt's explicit mission to find out what happened to Gentille. Moreover, it is also a quest for a format of this violence, or a form in which it can be comprehended, shown, and remembered so that its victims can also be remembered and actually be reconstituted from their annihilation.

Courtemanche's novel contains a particularly violent sequence toward the end of the book, as we learn about Gentille's suffering at the hands of her torturer Modeste, who, not incidentally, is Valcourt's ex-cameraman. In contrast, Favreau's movie adaptation presents us with a highly mediated and suggestive representation of this violence, and it is worthwhile to briefly compare. In the novel, after his return to Kigali as the forces of the Rwandese Patriotic Front sweep through the capital, Valcourt eventually gets Gentille's scribbled diary in his hands, and as readers of Courtemanche's novel, we get a gradual reconstruction of her gruesome ordeal - though, the end is left hanging, as the workbook entries stop with a quotation from Paul Élouard's Le Temps déborde: "We shall not grow old together / . . . My love so light now has the weight of torture" (2004, p. 247). Important here is that as readers, we acquire knowledge of Gentille's cruel demise in a cumulative way through several filters: that of novelist Courtemanche, whose omniscience fills in the gory details of the woman's horrific demise, that of the reader Valcourt, whose reconstructive need to know what happened is insatiable, and not in the least, the apparent calm words from the victim herself, Gentille, jotted down as haunting fragments in her diary. In his film adaptation, Favreau does not use a diary. Instead, he has Valcourt stumble into the house and shed where Gentille has been kept captive by Modeste. Through a visual re-assembly of three time references, which constantly alternate, we are witness to both Gentille's and Valcourt's point zero: the methodical, persistent and extended rape and eventual mutilation by Modeste and his Hutu Power zealots. Present-time sequences of Valcourt handling a soiled bit of dress, left on the floor as the only material left of the 24-year old woman, and emptily reaching out to her bloody imprints on the walr, alternate with the journalist's own videotaping of their courting, in which they had both decided to go for an opportunistic meeting of old versus young, white versus black, affluent versus poor: the stuff that Hollywood is made of, but now presented as an ideal, never reached. In these video-fragments, Gentille's smile of the past, which looks so much forward to the future, haunts the image of dark smudges of blood on the wall, with her voice in the background between hysterical suffering, and defiant erotic laughter, Favreau's response to Courtemanche's novel, where we read in her diary: "I've looked for pleasure in my pain" (247). The film's montage of this revelatory sequence is completed with the insertion of carefully constructed shots of Gentille's rape and torture, which we never get to see, but instead is inserted in fragmentary bits with hardly ever a direct exposure. The rape 
and torture is delicately mediated by means of shadows shots, and frames of Gentille's back as she is ruthlessly violated. These fragments are voiced over with Gentillle's words, which Robert Valcourt hears in his head, the latter being the equivalent of her diary and Paul Élouard's verse in the novel. Thus, Valcourt, together with the viewer, figuratively reconstruct and relive her suffering, but do so while not seeing, and not knowing, on a purely imaginative level. We get a filmic construction of the pierced eye metonym, where we are anxiously watching what is wounding us, and thus cannot be watched. That it is cameraman Modeste who wields the machete just completes the metonymic trope of the unwatchable see-able. Robert Favreau's mise-enscène and Pierre Mignot's camerawork here respond in a fascinating way to the notion that genocidal violence is always by definition obscured, and thus document the genocide's double obliteration: its murdered victims, as well as its obscured remembrance. The sequences of Gentille's torture, as Dauge-Roth points out, are indeed "a metonymy for the genocide's perpetration" and foreground primarily the inadequacy of what he calls "realism and its ideological trompe l'œil" 231). While together with Valcourt, we want to know, recompose and reconstruct those past events, even to the point ofmvoyeurism, such a project is doomed to fail. Remembrance can only happen through mediation, which is mostly a process of figuration. The impact of this figuration is such that it may increase the haunting effect of that remembrance.

Favreau'sfilm, ithasbecomeclear,departs in many ways from Courtemanche's novel. It does so, however, most drastically at its very conclusion. In both film as well as novel, Gentille ends up dead, but emphatically liveg on in Valcourt's memory. In the book, weakened by AIDS and other infections, and isolated because of her disfiguration and mutilation, she dies of a sudden pneumonia attack: "She is buried under the great fig tree that shades the hotel swimming pool" (Courtemanch4, A Sunday 258). In the film adaptation, Robert Valcourt continues his quest for Gentille in search of the facts of her demise, and ends up in her nativl village, where he had earlier asked her father for her hand. He meets Désirée, the girl that survived the bloody onslaught of her parents Cyprien and Georgina, and who now, in a role-reversal, takes care of her foster mother, Gentille who somehow has been able to make her way back to her village. Disfigured, infected and infectious, deathly ill, and hardly human, in her father's burntout house, which is situated in an area which otherwise looks like paradise, she reminds Valcourt of his promise "not to leave her behind," resulting in an altruistic killing: Valcourt smothers her, lying in his arms, with a pillow over her face. ${ }^{9}$ In contrast to the earlier montage and obscuration of the rape and torture - a death that cannot be rememberedthis happens in traditional realist style, re-enacted in front of Favreau's camera 
and part of the main story of the film. This scene tells us that death is most certainly available for the camera to be filmed, though only that kind of death in which one has some agency. Here are two human beings, who, while cornered because of circumstances, have taken a decision that acquires public consequence and weight. It also brings about a remarkably diverse distribution of death in the film, where people die of AIDS -Valcourt's initial focus at the beginning of his journey, when we learn that, unofficially, close to $35 \%$ of Kigali's population is seropositive, with disc-jockey Rock's spun out demise early on in the film serving as an emblematic occurrence of this kind of death. As the film goes on, death as the result of genocidal atrocity occupies the central place, and diverts Valcourt's focus away from AIDS for most of the filmic narrative. Finally, as is the case with Gentille, some people die through an act of love - Valcourt's final resolve in which he keeps his promise not to leave her behind. It is remarkable that in a film on the Rwandan genocide, the only sort of death that is extensively shown, in full realist aesthetics, is the latter one: Gentille's calm, calledfor and deliberate, tearful death on a grubby bed, in the arms of her lover.

The film ends then, with Valcourt carrying Gentille's corpse outside of the sombre hut, into the yard of her father's home, where she is to be buried. Valcourt is joined by Désirée, and we get a panoptic view of the paradisiac surroundings of this country of a thousand hills, this "little Switzerland in Africa," which is now shockingly empty of people, after 100 days of hell, leaving scars everywhere. Favreau uses light in a very special way in his film, and it acquires a major semiotic function as a sort of formal mise-enabyme. Throughout the film, all scenes that are in the performative present and document Valcourt's return after the violence, and his quest for Gentille are filmed through a light filter, making them dull and grey, showing a country in mourning, with poignantly gloomy and dim colours. This is how the film starts, as Valcourt commences his quest for answers. The dreary effect is in great contrast to both Valcourt's videography, as well as the scenes in which we flashback to the time leading up to the outburst of violence, which shows a country and people marked by sprightly, vivid colours, the green of its lush vegetation conspicuously jumping to the eye. The film ends, however, in full colour, without the dulling filter, with the brighter inner temporal frames taking over the gloomy present in a bright symbiosis. Valcourt places his video-camera on Gentille's gravemound, and plays the vivid colours of his videoclips, showing Gentille and Désirée fully and stunningly beautifully alive, while the two survivors and Désirée and Valcourt, black and white, young and old, orphan and widower, native and foreigner, look on in perfect harmony, against the backdrop of the vibrant colours of the verdant thousands hills, reflecting the central pre-genocide temporal framework of the film. To 
use an earlier trope, the watching double-layered eye of the viewer is now restored, no longer pierced by maiming steel, even the lacerations' sutures seem now to have healed.

Dauge-Roth finds in this concluding scene an emphatic statement of the camera's power serving the necessity to remember, and keeping the memory afresh:anantidoteagainst "obliteration" and the "ideology of denial" 234). It is certainly a gripping mise-en-abyme, in which the film's different temporal as well as narrative frames come together touchingly. However, to end a film on one of the most tragic socio-political conflicts in human history in this kind of intimate memorialization also comes at a cost. While Robert Favreau seems to suggest that genocidal violence cannot be photographed nor filmed, he also emphasizes the camera's ability to narrate and conjure the subjective story. The film has little room for political referencing and explication, which is perhaps best illustrated by its consistent use of first names, also when it concerns characters that are modeled after reallife players and agents in the conflict. Yet, there is subtle and consistent inclusion of historical factors, such as the hatebroadcasts of Radio Télévision Libre des Mille Collines, the shooting down of Habyarimana's airplane, the AIDS epidemic, and, rather hyperbolically, the role of the Hotel des Mille Collines as a place of refuge. Yet, in spite of the film's documentary underpinnings, it remains very much an emblematic excursion of one person's story, and this is hugely emphasized at the very end, leading some commentators to call the film "myopic" (Pevere). Contrary to what Dauge-Roth seems to suggest, there is very little "archival value" 234) in A Sunday in Kigali. The arbitrariness of the title itself, apart from its slight reduction of the novel's title,${ }^{10}$, is only a first indication of its lack of archival or even documentary value. It tells a gripping story, and does so intelligently, with a good level of self-reflection, and with an à-propos use of filmic signage. However, when at the end of the movie, the symbiotic scene between Désirée and Valcourt ends the film on a positive and hopeful note, its awkward and friable point de départ of a white journalist telling his story of not being able to save Rwanda remains even more difficult to embrace. In the end, we wonder who do we need to feel sorry for?

In her summation of twentieth century genocides, 'A Problem from Hell.' America and the Age of Genocide, Samantha Power reminds us of an incident during the many press conferences at the U.S. State department during the Rwanda crisis. Prudence Bushnell, Deputy Assistant Secretary, had recommended proactive and determined intervention just weeks before the commencement of the genocide, and gave a press conference, on April 8 1994, to warn of the escalating violence. The department's spokesperson, Michael McCurry then took over and critiqued foreign governments for not heading the message that was promulgated in Steven Spielberg's film Schindler's List, which he called a must-see so that people can 
learn that even one individual can make a difference in such an overwhelming conflict. He even recommended that the film, which had been released just the year before, be shown around the globe, as one of the most efficient measures to prevent the tragedy of genocide 392). His promotion of a US cultural product served mostly to offset Bushnell's implied criticism on her own government and its non-action. It also was no surprise to hear this spokesperson promote a foreign policy based on individual heroism, as opposed to sustained critical support of political emancipation. Be it as it may, his odd recommendation is also testimony to the power of film in our day and age. A film like A Sunday in Kigali certainly has a strong impact on our memorialization of genocide and political violence, but its seductive subjectivity in its own narrative also stands in the way of a more historically based political grasping of what happened leading up to and during the conflict. Its greatest merit, however, is in its admission that film, simply, cannot archive death and the blood that comes with it.

\section{Works Cited}

Ball, Karyn. "Unspeakable Differences, Obscene Pleasures: The Holocaust as an Object of Desire." Women in German Yearbook 19. 2003. 20-49. Print.

Bond, Edward. Plays: Two. London: Methuen, 1978. Print.

---. "From Rationalism to Rhapsody." Interview with Christopher Innes. Canadian Theatre Review 23 (1979): 108-13. Print.

Caton-Jones, Michael. "Interview." Shooting Dogs. 2006. DVD.

---. Shooting Dogs. Great-Britain-Germany. 2005.. Chrétien, et al. Rwanda. Les médias du genocide. Paris: Karthala, 1995. Print.

Courtemanche, Gil. Un dimanche à la piscine à Kigal. Paris: Éd. Denoël, 2000-2003. Print.

---. A Sunday at the pool in Kigali. Trans. Patricia Claxton. Toronto: Vintage, 2004. Print.

Dallaire, Roméo and Brent Beardsley. Shake Hands with the Devil. Toronto: Vintage, 2004. Print.

Dauge-Roth, Alexandre. Writing and Filming the Genocide of the Tutsis in Rwanda. Lanham: Lexington, 2010. Print.

Defraeye, Piet. "Twice at Peril... The Rwandan Genocide in Cultural Discourse. A Survey with Special Focus on Gil Courtemanche's Un dimanche à la piscine à Kigali." In Ursula Mathis-Moser, ed. Responsibilty to Protect. Peacekeeping, Diplomacy, Media, and Literature Responding to Humanitarian Challenges. (Canadiana oenipontana 11) Innsbrück: Innsbrück UP, 2010. 175-204. Print.

De Temmerman, Els. De doden zijn niet dood. Rwanda, een ooggetuigenverslag. Groot Bijgaarden (B): Globe, 1994. Print.

Favreau, Robert. Un dimanche à Kigali. 2008. DVD. 
Härting, Heike. "Global Humanitarianism, Race, and the Spectacle of the African Corpse in Current Western Representations of the Rwandan Genocide." Comparative Studies of South Asia, Africa and the Middle East. 28.1 (2008): 61-77. Print.

Hatzfeld, Jean. The Antelope's Strategy: Living in Rwanda after the Genocide. New York: Picador, 2009. Print.

Peck, Raoul. Sometimes in April. 2004. DVD.

Pevere, Geoff . "A view of Kigali from the Hotel Bar.” Toronto Star. 22 Sept 2006: C3. Print.

Power, Samantha . "Een problem uit de hel." Amerika, het Westen en het tijdperk van de genocide. Amsterdam: Olympus, 2003.

Sontag, Susan. Regarding the pain of Others. New York: Farrar, Straus and Giroux, 2003. Print.

Thompson, Al. "The Father and Daughter we Let down.” 2009. Web. 6 Dec 2010. <http://www.thestar.com/News/Insight/ article/616860>.

Todts, Herwig. Ensor Revealed. Brussels: ING and Fonds Mercator, 2010. Print.

\section{(Endnotes)}

1 For a critical survey of cultural discourse on the Rwandan Genocide, see my chapter "Twice at Peril... The Rwandan Genocide in Cultural Discourse,. A Survey with Special Focus on Gil Courtemanche's 'Un dimanche à la piscine à Kigali' Ursula Msthis-Moser (ed.), Responsibility to Protect (canadiana oenipontana 11. Innsbrück, Innsbrück UP, 2012. 175-204

2 The film was released in North America under the title Beyond the Gates.

3 See Ndahiro, Alfred and Privat Rutazibwa, Hotel Rwanda or the Tutsi Genocide as Seen by Hollywood (Paris: L'Harmattan, 2008).
4 For a good presentation of the role of the Rwandese media before the actual genocide, see Jean-Pierre Chrétien, et al Rwanda. Les médias du genocide (Paris: Karthala, 1995).

5 My Dead Mother IV (with wide open eyes) in Todts 218.

6 For the original footage, and Al Thompson's commentary, see http://www.thestar.com/ News/Insight/article/616860.

7 Nick Hughes himself suggests there are actually three, as reported by Dauge-Roth (222).

8 Another fictional character, Mons. Lamarre, conspicuously breaks the naming convention by being named ONLY by his surname. He is Caucasian, and a rather inept and naive bureaucrat at the Canadian Embassy in Kigali. The cast roll-call at the end of the film stands out because it only uses first names for the characters, with the exceptions mentioned here.

9 This scene is remarkably similar to the altruistic killing of the histrionic Countess, by her son Vallier in John Greyson's Lilies (1996), another Quebecois film, an adaptation of Michel Marc Bouchard's play Les Feluettes (1987).

10 The novel's title refers, somewhat capriciously, to the Sunday afternoon when Valcourt and Gentille get married, just before the escalation of the genocide. In the film, they never get married, apart from a private pledging between the two of them. 
Piet Defraeye is a drama theorist, critic and director, who taught and directed in Belgium, Toronto, and Fredericton (N.B.) and at the University of Alberta (Edmonton). He has published on Irish and Quebec Theatre, German contemporary performance, film/ opera and theatre, and gender/queer theory and Reception Theory. He has embarked on a large research project that focuses on the iteration of genocide in Cultural Discourse with a special focus on Rwanda. His most recent creation is linked to his research on genocidal representation with his theatrical adaptation of Raymond Federman's The Voice in the Closet (2012).
Piet Defraeye est théoricien du théâtre, critique, et metteur en scène. Il a enseigné en Belgique, à Toronto, à Fredericton (N.B), et à Edmonton (à l'Université de l'Alberta). Il a publié sur les théâtres irlandais et québécois, sur la performance, l'opéra, le cinéma et le théâtre allemands contemporains, de même que sur la théorie queer et la théorie de la réception. Il a entrepris un projet de grande envergure sur l'itération du génocide dans le Discours Culturel avec une concentration sur le Rwanda. Sa plus récente création en fait partie : une adaptation de The voice in the Closet de Raymond Federman (2012).

Copyright Piet Defraeye. This article is licensed under a Creative Commons 3.0 License although certain works referenced herein may be separately licensed, or the author has exercised their right to fair dealing under the Canadian Copyright Act. 